University of Nebraska - Lincoln

DigitalCommons@University of Nebraska - Lincoln

Faculty Papers and Publications in Animal

Science

Animal Science Department

1994

\title{
Electromagnetic Scanning of Beef Quarters to Predict Carcass and Primal Lean Content
}

\author{
B. L. Gwartney \\ University of Nebraska-Lincoln \\ Chris R. Calkins \\ University of Nebraska-Lincoln, ccalkins1@unl.edu \\ R. S. Lin \\ Purdue University \\ J. C. Forest \\ Purdue University
}

Anne M. Parkhurst

University of Nebraska-Lincoln, aparkhurst@unl.edu

See next page for additional authors

Follow this and additional works at: https://digitalcommons.unl.edu/animalscifacpub

Part of the Animal Sciences Commons

Gwartney, B. L.; Calkins, Chris R.; Lin, R. S.; Forest, J. C.; Parkhurst, Anne M.; and Lemenager, R. P., "Electromagnetic Scanning of Beef Quarters to Predict Carcass and Primal Lean Content" (1994). Faculty Papers and Publications in Animal Science. 594.

https://digitalcommons.unl.edu/animalscifacpub/594

This Article is brought to you for free and open access by the Animal Science Department at DigitalCommons@University of Nebraska - Lincoln. It has been accepted for inclusion in Faculty Papers and Publications in Animal Science by an authorized administrator of DigitalCommons@University of Nebraska - Lincoln. 


\section{Authors}

B. L. Gwartney, Chris R. Calkins, R. S. Lin, J. C. Forest, Anne M. Parkhurst, and R. P. Lemenager 


\title{
Electromagnetic Scanning of Beef Quarters to Predict Carcass and Primal Lean Content ${ }^{1,2}$
}

\author{
B. L. Gwartney*, C. R. Calkins*, R. S. Lin ${ }^{\dagger}$, J. C. Forrest ${ }^{\dagger}$, A. M. Parkhurst ${ }^{\ddagger}$, \\ and $\mathbf{R}$. $P$. Lemenager ${ }^{\dagger}$
}

*Animal Science Department, University of Nebraska, Lincoln 68583-0908, tDepartment of Animal Sciences, Purdue University, West LaFayette, IN 47906, Department of Biometry, University of Nebraska, Lincoln 68583-0712

\begin{abstract}
To study the use of electromagnetic scanning in prediction of lean content in beef carcasses and cuts, 100 beef cattle ( 60 steers and 40 heifers), representing a broad range in external fat thickness $(.1$ to $2.9 \mathrm{~cm})$ and live weight $(414$ to $742 \mathrm{~kg})$, were selected. Chilled right sides were divided into streamlined (foreshank, brisket, and ventral plate removed) forequarters $(\mathrm{FQ})$ and full hindquarters $(\mathrm{HQ})$ and scanned. Primal rounds, loins, ribs, and chucks were fabricated from the right side, scanned, and physically separated into lean, fat, and bone. Prediction equations for dissected lean content and percentage of lean included the peak of the electromagnetic scan response curve (obtained from scanning the $\mathrm{HQ}$ or $\mathrm{FQ}$ ), length, temperature and weight of the scanned cut, and fat thickness at the 12th rib. Using the coefficient of determination, root mean square error, and Mal-
\end{abstract}

lows' $\mathrm{Cp}$ statistic, the best model for each dependent variable (weight and percentage of lean) that included up to five independent variables was selected. Prediction equations for the $\mathrm{HQ}$ or $\mathrm{FQ}$ of steers accounted for 84 to $93 \%$ of the variation in lean weight of beef sides and quarters and 71 to $93 \%$ of primals. Sixty-one to $75 \%$ of the variation in percentage of lean in sides and quarters and 48 to $65 \%$ of primals was also explained. Similar results were obtained for heifer carcasses. Predicting percentage of lean in any scanned cut, rather than weight of lean, accounted for less of the variation. Weight and fat thickness contributed significantly when predicting percentage of lean. These data indicate that electromagnetic scanning is capable of objectively measuring lean content in beef quarters and primals.

Key Words: Electromagnetic Fields, Scanning, Beef, Composition

J. Anim. Sci. 1994. 72:2836-2842

\section{Introduction}

Renewed interest in value-based marketing has sparked a wave of research on new technology and procedures to objectively measure composition of beef carcasses. Electromagnetic scanning ( EMS) may be a desirable method because it is fast, accurate, noninvasive, and reliable.

In one of the first applications of EMS, Domermuth et al. (1976) reported that EMS could predict carcass protein $\left(\mathrm{R}^{2}=.80\right)$ in live pigs. Using improved sensing technology, results in the medical field have shown strong correlations between EMS and predicted total body water $(\mathrm{r}=.87$, Presta et al., 1983; $\mathrm{r}=.99$,

\footnotetext{
${ }^{1}$ Published as paper no. 10401, Journal series, Nebraska Agric. Res. Div.

${ }^{2}$ Funded in part by the Beef Industry Council of the National Live Stock and Meat Board.

Received March 21, 1994.

Accepted July 18, 1994.
}

Cochran et al., 1988). Others have indicated EMS correlates highly $(\mathrm{r}>.99)$ with fat-free mass in miniature pigs and rabbits (Fiorotto et al., 1987).

Electromagnetic scanning can account for 85 to $90 \%$ of the variation in lean content of beef quarters and primals from a homogeneous population of steer carcasses (Gwartney et al., 1992). Further research is needed to determine the potential for beef carcasses from a more heterogeneous population that includes heifers and steers. The objective of this study was to determine whether electromagnetic scanning is effective in predicting lean content of beef carcasses, quarters, and primals that are diverse in weight and fat thickness.

\section{Materials and Methods}

One hundred beef cattle ( 60 steers and 40 heifers) representing a wide range in live weight and external fat thickness (Figure 1) were selected for evaluation 


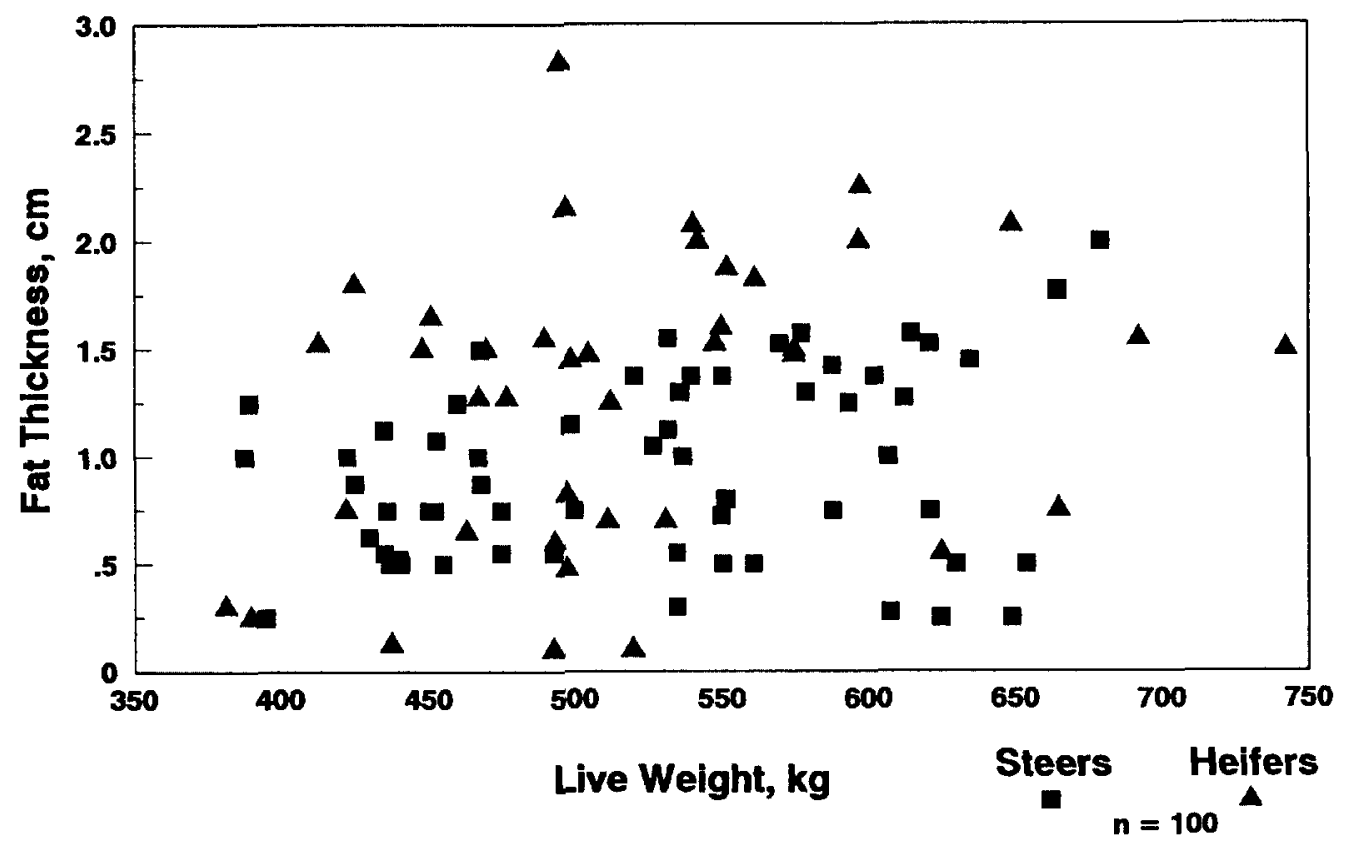

Figure 1. Fat thickness and live weight grid for steer and heifer scanning population.

of their carcasses and cuts using electromagnetic scanning. Cattle were slaughtered at Purdue University.

Immediately after carcasses were split, the warm right sides were fabricated into hindquarters (HQ) and forequarters (FQ) between the 12th and 13th rib to allow scanning of hot quarters (data not reported). After chilling for $24 \mathrm{~h}$, USDA carcass quality and yield grade data were obtained on the left sides. The FQ was fabricated to produce a streamlined FQ (brisket, foreshank, and ventral plate removed) to meet the size limitations of the scanner. Length, internal temperature, and weight were recorded on the right $\mathrm{HQ}$ and $\mathrm{FQ}$ before scanning posterior to anterior. Length of the quarters and cuts was measured as the longest linear distance from one end of the cut to the other. Internal temperatures were measured in the center of the deepest portion of the round and chuck using a probe-like thermocouple. Each quarter and untrimmed primal was scanned twice through a model MQ-25 electromagnetic scanner (Meat Quality, Springfield, IL).

After scanning the $\mathrm{HQ}$ and streamlined $\mathrm{FQ}$, the chilled quarters were separated into the primal round (IMPS 158), loin (IMPS 172), chuck (IMPS 113), rib (IMPS 103), flank, and dorsal portion of the plate (USDA, 1988). The round, loin, rib, and chuck were then scanned, posterior to anterior, and length and weight were recorded. All cuts from the right side were then bagged in plastic and shipped to the University of Nebraska. Each cut was dissected into lean, bone and heavy connective tissue, intermuscular fat, and subcutaneous fat.

Dissected lean from each cut was then ground through a coarse plate (kidney-shaped holes about 25 $\mathrm{mm} \times 50 \mathrm{~mm}$ ) and mixed. Half of the coarse-plateground lean was ground through a $25-\mathrm{mm}$ plate and mixed, and half of that lean was ground through a $5-\mathrm{mm}$ plate. A .5-kg subsample was frozen until further analysis. Frozen samples were then chopped into small pieces and powdered in a Waring blender (New Hartford, CT) containing liquid nitrogen. A representative sample was analyzed for moisture and lipid content (AOAC, 1987). This protocol was followed to calculate a fat-free dissected lean component for use as a dependent variable in the linear regression analysis. Results from this analysis were similar to those for dissected lean and thus are not included.

Statistical analyses included linear regression using SAS (1990). The prediction models for steers and heifers were tested for slope homogeneity using sex as a class variable and testing all sex $\times$ independent variable interactions (Milliken and Johnson, 1989). This analysis resulted in sex $\times$ class interactions; therefore, steer and heifer prediction models are presented as separate populations. To determine the best predictive model, all possible regression models containing one to five independent variables were evaluated using Mallows' $C p$ statistic, the $\mathrm{R}^{2}$, and the square root of the mean square error (residual standard deviation). The best prediction model contained the fewest number of variables when the $C p$ statistics was less than or equal to the number of parameters in the model, including the intercept. The dependent variables included total weight of dissectable lean and percentage dissectable lean for the side, $\mathrm{HQ}, \mathrm{FQ}$, and the four primals (round, loin, chuck, and rib). Independent variables included quarter weight, length, temperature, fat thickness ( $3 / 4$ fat depth), 


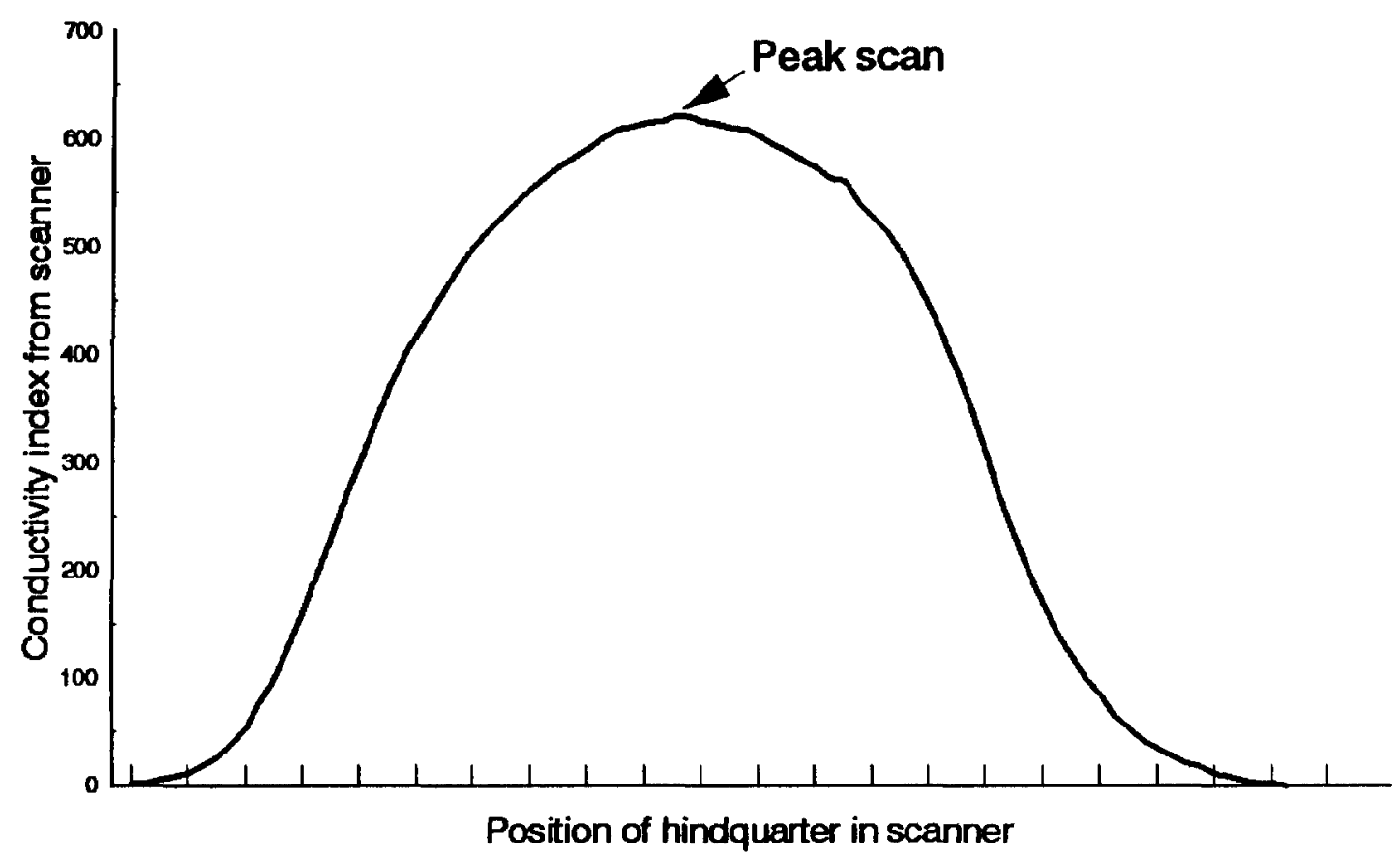

Figure 2. Example of the scan of a hindquarter showing the peak.

and the scan peak for each quarter. Custom-written software was used to analyze the scan curve (Figure 2 ). The software performs a serial average using 10 numbers in sequence. The initial unadjusted peak, a smoothed peak, and the total area under the curve were also obtained.

\section{Results and Discussion}

The goal of this study was to assess the ability of electromagnetic scanning to predict lean content in beef quarters and primal cuts. Electromagnetic scanning technology is based on the induction of a uniform current in the sample by placement within a characteristic low-frequency $(2.5 \mathrm{MHz})$ electromagnetic field (Harrison, 1987). The sensing field is present within a cylindrical volume $200 \mathrm{~cm}$ long and $66 \mathrm{~cm}$ in diameter (Funk, 1991). An oscillating current of a specified radiofrequency is applied to the coil, creating the electromagnetic field in the empty cylinder. The difference in energy absorption, within the empty coil and as the sample moves through the scanner, is recorded. Multiple readings (up to $80 / \mathrm{s}$ ) are taken.

The difference in the energy absorption is due to two factors: the conductive and the dielectric properties of the sample. The conductive properties are due to ions within the soft tissue, especially within the lean body mass, that make lean tissue somewhat conductive. Metals, which are highly conductive, absorb little energy; fat and bone are highly resistive and also absorb little energy. Conductivity in the electromagnetic field is a result of the ionic content of the sample and is highly correlated with lean body mass and total body water (Harrison, 1987; Van Loan and Mayclin, 1987; Cochran et al., 1988). Dielectric properties, which are due to the sample's geometry, also influence energy absorption. This includes the sample's length, which is an important variable in prediction equations, and circumference. A potential advantage of this technology is a direct indication of lean content, relatively free from biases of different breed or genotype ( $\mathrm{Gu}$ et al., 1992).

Electromagnetic scanning has been shown to be effective in predicting the amount of lean in pork carcasses (Forrest et al., 1989). Limited work has been conducted with beef carcasses or cuts. Lin et al. (1992) showed that the conductivity index (called scan peak in this paper) is the most important variable when predicting lean mass in large beef cuts.

Tables 1 and 2 characterize the population of steers and heifers used in the study. There were 60 steers and 40 heifers ranging in live weight from 414 to 742 $\mathrm{kg}$ and ranging in fat thickness from .10 to $2.87 \mathrm{~cm}$. Broad heterogeneity was intended in this study, so that an accurate representation of the beef carcass population would be obtained.

Tables 3 to 6 contain the $\mathrm{R}^{2}$, the root mean square error ( RMSE), Mallows' Cp statistic, and regression coefficients for the best model for each variable. The best prediction model was selected by maximizing the $\mathrm{R}^{2}$, minimizing the RMSE, and selecting the $\mathrm{Cp}$ statistic that approaches the number of parameters in the model, including the intercept, from all possible models (Mallows, 1973). For every dependent variable, the peak scan and fat thickness were included in 
Table 1. Mean live and carcass characteristics for steers ${ }^{a}$

\begin{tabular}{lcccc}
\hline \hline Variable & Mean & SD & Minimum & Maximum \\
\hline Live wt, kg & 544 & 69 & 424 & 672 \\
Warm carcass wt, kg & 339 & 47 & 252 & 431 \\
Fat thickness, cm & .96 & .43 & .25 & 2.03 \\
Longissimus muscle area, cm 2 & 80.6 & 10.7 & 53.9 & 104.0 \\
Kidney, pelvic, and heart fat \%, estimated & 3.05 & .79 & 1.50 & 6.30 \\
Yield grade & 2.93 & .73 & 1.00 & 4.38 \\
\hline an = 60. & & & & \\
bAdjusted fat thickness at the 12th rib. & & & &
\end{tabular}

the predictive model; weight was included most of the time. Temperature and length were interchangeable as the fifth variable in the predictive equations. In all cases, the $R^{2}$ represents the amount of variation explained by the best model obtained from scanning. The RMSE indicates the standard deviation of the predicted value.

Analysis of a fat-free lean end point resulted in $\mathrm{R}^{2}$ equal to or, in most cases, lower than that of the dissected lean component (data not included). Table 3 presents the results from scanning the $\mathrm{HQ}$ of steers and the best models containing four of the five independent variables that included the $H Q$ scan peak, HQ temperature, length, weight, and fat thickness. In all but one case, length was not included in the prediction equation for weight of dissected lean; the same was true for predicting percentage lean. Scanning the HQ resulted in $\mathrm{R}^{2}$ ranging from .84 to .93 for lean weight and .69 to .76 for percentage of lean of sides or quarters. In general, the electromagnetic scans predicted $\mathrm{HQ}$ lean (weight and percentage) and the $\mathrm{HQ}$ primal lean (round and loin) better than scans of $F Q$ predicted $F Q$ lean and lean in its primals (chuck and rib). The greater lean mass in the HQ probably accounts for these results. These data are consistent with those reported by Gwartney et al. (1992) for a homogenous population of beef steer carcasses.

When the FQ was scanned for prediction purposes, temperature, quarter length, or weight were the independent variables not included in the model, depending on the predicted cut (Table 4). The FQ scans resulted in $\mathrm{R}^{2}$ ranging from .87 to .93 for weight of lean in the side and quarter and accounted for .71 to .86 of the variation in lean content of the primals. The $\mathrm{R}^{2}$ ranged from .61 to .64 for the side and quarter lean percentage and .48 to .59 for predicting lean percentage of the primals. The $F Q$ scans, for the most part, were best at predicting $F Q$ and $F Q$ primal lean weight and percentage.

The results from heifer carcasses were similar to those obtained from steers (Tables 5 and 6 ). The $\mathrm{R}^{2}$ were 5 to $10 \%$ higher for the heifers than for the steers for most cuts. Although the heifers were more variable in their carcass traits (Table 2), there were fewer heifer than steer carcasses sampled. Perhaps this variation accounts for the higher $R^{2}$ values. The best four variable models excluded either quarter length or temperature, depending on the dependent variable in question.

Because electromagnetic scanning measures amount of lean and is little influenced by fat, prediction of percentage of lean was less successful than prediction of weight of lean. Cuts or quarters containing the same weight of lean but different weight of fat would have grossly different percentages of lean, which would not be detected by measuring only lean. All models for predicting percentage of lean in steers and heifers contained $3 / 4$ fat depth and quarter weight. Fat thickness was included in the regression equations. This would help overcome the limitation of the EMS unit, because it cannot measure fat. Fat thickness significantly reduced bias $(\mathrm{Cp})$ in the models.

Table 2. Mean live and carcass characteristics for heifers ${ }^{a}$

\begin{tabular}{lcccc}
\hline \hline Variable & Mean & SD & Minimum & Maximum \\
\hline Live wt, kg & 539 & 72 & 414 & 742 \\
Warm carcass wt, kg & 333 & 49 & 229 & 457 \\
Fat thickness, cm & 1.29 & .67 & .10 & 2.87 \\
Longissimus muscle area, cm ${ }^{2}$ & 82.2 & 11.0 & 58.5 & 109.5 \\
Kidney, pelvic, and heart fat \%, estimated & 3.71 & 1.08 & 1.50 & 6.40 \\
Yield grade & 3.23 & .86 & 1.22 & 5.07 \\
\hline an $=40$. & & & & \\
bAdjusted fat thickness at the 12th rib.
\end{tabular}


Table 3. Regression analyses predicting lean weight and percentage using hindquarter scans from steers

\begin{tabular}{|c|c|c|c|c|c|c|c|c|c|}
\hline \multirow[b]{2}{*}{ Variable } & \multirow[b]{2}{*}{$\mathrm{R}^{2}$} & \multirow[b]{2}{*}{$\mathrm{Cp}^{\mathrm{a}}$} & \multirow[b]{2}{*}{ RMSE $^{\mathbf{b}}$} & \multirow[b]{2}{*}{ Intercept } & \multicolumn{5}{|c|}{ Regression coefficient } \\
\hline & & & & & PEAK & LENGTH & TEMP & WEIGHT & $3 / 4 \mathrm{FAT}$ \\
\hline \multicolumn{10}{|l|}{ Weight of lean } \\
\hline SIDE & .928 & 4.08 & 3.23 & 27.2553 & .0563 & - & -.4655 & .5684 & -6.0722 \\
\hline $\operatorname{SIDE}^{\mathrm{c}}$ & .934 & 4.26 & 2.87 & 21.2562 & .0483 & - & -.4740 & .5638 & -5.3598 \\
\hline HINDQTR & .942 & 4.44 & 1.58 & 9.1617 & .0368 & - & -.0724 & .2664 & -3.0185 \\
\hline ROUND & .908 & 4.07 & 1.14 & 3.2646 & .0265 & .0354 & - & .0765 & -1.6011 \\
\hline LOIN & .883 & 6.05 & .86 & 1.1848 & .0077 & - & -.0993 & .1500 & -1.4194 \\
\hline FOREQTR & .848 & 4.00 & 2.24 & 18.0936 & .0195 & - & -.3931 & .3020 & -3.0537 \\
\hline FOREQTR $^{\mathrm{d}}$ & .855 & 4.05 & 1.86 & 12.0945 & .0115 & - & -.4016 & .2974 & -2.3413 \\
\hline CHUCK & .781 & 4.28 & 1.55 & 12.0148 & .0069 & - & -.3361 & .1911 & -1.4883 \\
\hline RIB & .711 & 5.04 & .61 & 2.0441 & .0049 & - & -.0846 & .0420 & -.4770 \\
\hline \multicolumn{10}{|c|}{ Percentage of lean } \\
\hline SIDE\% & .752 & 4.02 & 1.78 & 67.2947 & .0322 & - & -.0295 & -.2948 & -3.3875 \\
\hline SIDE\% $\%^{\mathrm{c}}$ & .747 & 4.00 & 1.86 & 70.4683 & .0311 & - & -.0579 & -.3085 & -3.4837 \\
\hline HINDQTR\% & .767 & 4.03 & 1.98 & 64.0214 & .0434 & - & -.2562 & -.2862 & -3.8879 \\
\hline ROUND $\%$ & .514 & 4.14 & 2.38 & $\mathbf{5 9 . 4 0 7 2}$ & .0251 & .0377 & - & -.1274 & -2.9965 \\
\hline LOIN\% & .657 & .4 .47 & 2.82 & 67.0388 & .0358 & - & -.4201 & -.2024 & -5.7015 \\
\hline FOREQTR\% & .703 & 4.02 & 1.91 & 73.2155 & .0267 & - & -.1681 & -.3418 & -2.1885 \\
\hline FOREQTR\% ${ }^{\mathrm{d}}$ & .695 & 4.03 & 2.32 & 83.1591 & .0222 & - & -.2982 & -.3937 & -2.1214 \\
\hline CHUCK\% & .627 & 4.39 & 3.20 & 92.9239 & .0157 & - & -.2731 & -.4544 & -.8891 \\
\hline RIB\% & .567 & 5.13 & 2.90 & 60.6197 & .0351 & - & -.3991 & -.2204 & -4.2022 \\
\hline
\end{tabular}

${ }^{\mathrm{a}} \mathrm{Cp}=$ Mallows' $\mathrm{Cp}$ statistic for model selection.

${ }^{\mathrm{b}} \mathrm{RMSE}=$ root mean square error $\mathrm{kg}$, $\%$ on bottom half.

${ }^{\mathrm{c}} \mathrm{SIDE}=$ side lean without foreshank, brisket, or ventral portion of the plate.

${ }^{\mathrm{d} F O R E Q T R}=$ forequarter lean without foreshank, brisket, or ventral portion of the plate.

Generally, scanning the $\mathrm{HQ}$ does a better job of predicting side, $\mathrm{HQ}$, round, and loin lean content than does scanning the $F Q$. The reverse is true for the $F Q$, rib, and chuck; FQ scans were most useful here. As the amount of lean being scanned increases, the results tend to be of greater magnitude. Greater mass gives

Table 4. Regression analyses predicting lean weight and percentage using forequarter scans from steers

\begin{tabular}{|c|c|c|c|c|c|c|c|c|c|}
\hline \multirow[b]{2}{*}{ Variable } & \multirow[b]{2}{*}{$\mathrm{R}^{2}$} & \multirow[b]{2}{*}{$C p^{a}$} & \multirow[b]{2}{*}{$\mathrm{RMSE}^{\mathrm{b}}$} & \multicolumn{6}{|c|}{ Regression coefficient } \\
\hline & & & & Intercept & PEAK & LENGTH & TEMP & WEIGHT & $3 / 4 \mathrm{FAT}$ \\
\hline \multicolumn{10}{|l|}{ Weight of lean } \\
\hline SIDE & .909 & 5.43 & 3.38 & 27.4491 & .1152 & .1662 & - & .2268 & -4.8344 \\
\hline $\operatorname{SIDE}^{\mathrm{c}}$ & .935 & 5.07 & 2.67 & 24.2100 & .1384 & .2101 & .3465 & - & -2.7480 \\
\hline HINDQTR & .882 & 4.00 & 2.18 & 9.6614 & .0816 & .1241 & .4108 & - & -2.1220 \\
\hline ROUND & .801 & 4.00 & 1.64 & 5.7898 & .0445 & .0768 & .2312 & - & -1.9095 \\
\hline LOIN & .860 & 4.05 & .88 & 2.4228 & .0296 & .0473 & .1168 & - & -.5651 \\
\hline FOREQTR & .871 & 4.01 & 1.85 & 15.0010 & .0390 & .0719 & - & .1854 & -2.3701 \\
\hline FOREQTR $^{\mathrm{d}}$ & .911 & 5.03 & 1.33 & 12.1778 & .0434 & .0587 & - & .1043 & -1.2065 \\
\hline CHUCK & .811 & 4.39 & 1.29 & 16.1019 & .0292 & - & -.1720 & .0653 & -.7194 \\
\hline RIB & .713 & 4.08 & .60 & 1.7113 & .0065 & - & -.0686 & .0481 & -.6159 \\
\hline \multicolumn{10}{|c|}{ Percentage of lean } \\
\hline SIDE\% & .646 & 5.63 & 2.24 & 69.6185 & .0443 & - & .2856 & -.2774 & -4.2542 \\
\hline $\operatorname{SIDE} \% \mathrm{c}$ & .631 & 4.88 & 2.36 & 71.5808 & .0386 & - & .2372 & -.2635 & -4.4764 \\
\hline HINDQTR\% & .652 & 5.38 & 2.51 & 66.9264 & .0722 & .0568 & - & -.3778 & -4.3573 \\
\hline ROUND\% & .563 & 4.82 & 2.29 & 72.5239 & .0590 & - & .2938 & -.2641 & -3.0097 \\
\hline LOIN\% & .598 & 4.01 & 3.15 & 60.4262 & .0650 & .1648 & - & -.3601 & -5.4363 \\
\hline FOREQTR\% & 612 & 4.00 & 2.29 & 70.7503 & .0380 & .0732 & - & -.3678 & -2.6885 \\
\hline FOREQTR\% $\mathrm{d}$ & .624 & 4.22 & 2.68 & 83.0168 & .0168 & - & -.3819 & -.2954 & -3.2816 \\
\hline CHUCK\% & .591 & 4.04 & 3.46 & 92.5602 & .0037 & - & -.3798 & -.3431 & -1.8397 \\
\hline RIB\% & .486 & 4.95 & 3.34 & 50.1197 & .0469 & .1175 & - & -.2113 & -5.1778 \\
\hline
\end{tabular}

${ }^{\mathrm{a}} \mathrm{Cp}=$ Mallows' $\mathrm{Cp}$ statistic for model selection.

${ }^{\mathrm{b}} \mathrm{RMSE}=$ root mean square error $\mathrm{kg}$, \% on bottom half.

CSIDE = side lean without foreshank, brisket, or ventral portion of the plate.

dFOREQTR = forequarter lean without foreshank, brisket, or ventral portion of the plate. 
Table 5. Regression analyses predicting lean weight and percentage using hindquarter scans from heifers

\begin{tabular}{|c|c|c|c|c|c|c|c|c|c|}
\hline \multirow[b]{2}{*}{ Variable } & \multirow[b]{2}{*}{$\mathrm{R}^{2}$} & \multirow[b]{2}{*}{$\mathrm{Cp}^{\mathrm{a}}$} & \multirow[b]{2}{*}{$\mathrm{RMSE}^{\mathrm{b}}$} & \multicolumn{6}{|c|}{ Regression coefficient } \\
\hline & & & & Intercept & PEAK & LENGTH & TEMP & WEIGHT & 3/4 FAT \\
\hline \multicolumn{10}{|l|}{ Weight of lean } \\
\hline SIDE & .936 & 5.02 & 2.96 & 17.9259 & .0730 & .0789 & - & .5869 & -5.0774 \\
\hline $\mathrm{SIDE}^{c}$ & .928 & 5.39 & 2.66 & 24.44 & .0638 & - & -.3742 & .5530 & -5.0940 \\
\hline HINDQTR & .918 & 5.49 & 1.84 & 4.5828 & .0347 & .0455 & - & .3406 & -3.1791 \\
\hline ROUND & .859 & 4.82 & 1.37 & 2.3782 & .0227 & .0373 & - & .1613 & -1.6639 \\
\hline LOIN & .838 & 4.11 & .92 & 2.6346 & .0085 & - & -.1348 & .1511 & -1.3062 \\
\hline FOREQTR & .892 & 4.17 & 1.79 & 13.3432 & 0382 & .0333 & - & .2463 & -1.8984 \\
\hline FOREQTR $^{\mathrm{d}}$ & .847 & 4.10 & 1.46 & 15.3140 & .0296 & - & -.2280 & .1702 & -1.3900 \\
\hline CHUCK & .749 & 4.30 & 1.41 & 14.0585 & .0224 & - & -.2151 & .1167 & -.8681 \\
\hline RIB & .807 & 4.01 & .49 & 2.1879 & .0072 & -.0082 & - & .0579 & -.5884 \\
\hline \multicolumn{10}{|c|}{ Percentage of lean } \\
\hline SIDE $\%$ & .798 & 4.02 & 2.41 & 68.4806 & .0417 & - & -.2671 & -.2238 & -4.6766 \\
\hline SIDE $\%^{c}$ & .799 & 4.06 & 2.47 & 69.9056 & .0385 & - & -.3006 & -.2373 & -4.7100 \\
\hline HINDQTR\% & .791 & 4.57 & 2.52 & 60.0563 & .0483 & .0572 & - & -.2565 & -4.3331 \\
\hline ROUND\% & .604 & 4.04 & 2.29 & 68.6643 & .0268 & - & -.4361 & -.0786 & -3.1383 \\
\hline LOIN\% & .836 & 4.40 & 2.25 & 65.7137 & .0264 & - & -.6152 & -.0560 & -6.6472 \\
\hline FOREQTR\% & .634 & 4.48 & 4.04 & 95.0407 & .0048 & -.0432 & - & -.1080 & -6.3865 \\
\hline FOREQTR\% & .682 & 4.00 & 2.77 & 89.0728 & .0004 & -.1011 & - & -.1077 & -4.4257 \\
\hline CHUCK $\%$ & .631 & 4.07 & 3.03 & 95.9187 & .0093 & -.1267 & - & -.0995 & -3.7527 \\
\hline RIB\% & .794 & 4.00 & 2.70 & 61.6268 & .0274 & - & -.3282 & -.0969 & 6.6650 \\
\hline
\end{tabular}

${ }^{\mathrm{a}} \mathrm{Cp}=$ Mallows' $\mathrm{Cp}$ statistic for model selection.

${ }^{\mathrm{R}} \mathrm{RSE}=$ root mean square error $\mathrm{kg}$, \% on bottom half.

cSIDE = side lean without foreshank, brisket, or ventral portion of the plate.

${ }^{\mathrm{d}}$ FOREQTR = forequarter lean without foreshank, brisket, or ventral portion of the plate.

higher instrument readings that are less affected by noise in the signal than are the smaller cuts (Lin et al., 1992). The size of the scanner should be propor- tional to the cut being scanned and the quarters scanned in this study satisfied this fundamental principle.

Table 6. Regression analyses predicting lean weight and percentage using forequarter scans from heifers

\begin{tabular}{|c|c|c|c|c|c|c|c|c|c|}
\hline \multirow[b]{2}{*}{ Variable } & \multirow[b]{2}{*}{$\mathrm{R}^{2}$} & \multirow[b]{2}{*}{$\mathrm{Cp} p^{a}$} & \multirow[b]{2}{*}{$\mathrm{RMSE}^{\mathrm{b}}$} & \multicolumn{6}{|c|}{ Regression coefficient } \\
\hline & & & & Intercept & PEAK & LENGTH & TEMP & WEIGHT & $3 / 4$ FAT \\
\hline \multicolumn{10}{|l|}{ Weight of lean } \\
\hline SIDE & .931 & 4.10 & 3.07 & 36.1489 & .0629 & - & .8295 & .5408 & -4.2820 \\
\hline $\operatorname{SIDE}^{\mathrm{c}}$ & .936 & 4.03 & 2.50 & 32.9140 & .0534 & - & .7566 & .4618 & -3.7094 \\
\hline HINDQTR & .934 & 4.04 & 1.63 & 17.2635 & .0414 & - & .5107 & .2140 & -2.0721 \\
\hline RDLEANKG & .923 & 4.03 & 1.01 & 10.8507 & .0264 & - & -.4002 & .0866 & -1.1763 \\
\hline LOINLNKG & .803 & 4.12 & 1.00 & 5.4317 & .0110 & - & -.0944 & .1008 & -.6924 \\
\hline FOREQTR & .870 & 4.43 & 1.98 & 18.8854 & .0214 & - & -.3188 & .3269 & -2.2098 \\
\hline FOREQTR $^{\mathrm{d}}$ & .847 & 4.01 & 1.47 & 15.6505 & .0119 & - & -.2460 & .2479 & -1.6373 \\
\hline CHUCK & .745 & 4.07 & 1.45 & 13.9943 & .0084 & - & -.1444 & .1792 & -1.1294 \\
\hline RIB & .798 & 5.07 & .49 & 1.6562 & .0035 & - & -.1015 & .0687 & -.5079 \\
\hline \multicolumn{10}{|c|}{ Percentage of lean } \\
\hline SIDE\% & .777 & 5.35 & 2.52 & 67.8458 & .0223 & - & -.4010 & -.2606 & -5.0341 \\
\hline SIDE\% ${ }^{\mathrm{c}}$ & .785 & 5.35 & 2.53 & 74.4451 & .0213 & -.0710 & - & -.2564 & -5.1444 \\
\hline HINDQTR\% & .794 & 4.50 & 2.50 & 64.6894 & .0288 & - & -.3771 & -.2462 & -5.2844 \\
\hline ROUND\% & .625 & 4.93 & 2.20 & 76.2295 & .0213 & -.0850 & - & -.1289 & -2.9902 \\
\hline LOIN\% & .834 & 4.72 & 2.27 & 67.5929 & .0160 & - & -.7768 & -.1014 & -6.6760 \\
\hline FOREQTR\% & .810 & 4.38 & 2.91 & 100.2 & .0344 & - & -.3916 & -.5817 & -4.0292 \\
\hline FOREQTR $^{\mathrm{d}}$ & .773 & 4.07 & 2.35 & 82.1146 & .0185 & - & -.3434 & -.4049 & -2.8393 \\
\hline CHUCK $\%$ & .702 & 4.00 & 2.73 & 86.3607 & .0154 & - & -.0321 & -.4315 & -1.9375 \\
\hline RIB $\%$ & .834 & 5.81 & 2.39 & 66.3750 & .0286 & - & -.5123 & -.2897 & -5.7473 \\
\hline
\end{tabular}

${ }^{\mathrm{a}} \mathrm{Cp}=$ Mallows' $\mathrm{Cp}$ statistic for model selection.

${ }^{\mathrm{b}} \mathrm{RMSE}=$ root mean square error $\mathrm{kg}$, $\%$ on bottom half.

'SIDE = side lean without foreshank, brisket, or ventral portion of the plate.

${ }^{\mathrm{d}}$ FOREQTR = forequarter lean without foreshank, brisket, or ventral portion of the plate. 


\section{Implications}

Electromagnetic scanning is a new technology that satisfies the criteria for being an effective tool for use in a value-based marketing system for beef carcasses, quarters, and primal cuts. The predictions of the varying cuts are accurate, as demonstrated by the high coefficients of determination and low root mean square errors. Scanning is effective on a heterogenous population of carcasses with wide ranges in live weight and fat thickness. Further research is needed to determine the effectiveness of scanning primals to predict primal and quarter lean content.

\section{Literature Cited}

AOAC. 1987. Official Methods of Analysis (13th Ed.). Association of Official Analytical Chemists, Washington, DC.

Cochran, W. J., W. W. Wong, M. L. Fiorotto, H.-P. Sheng, P. D. Klein, W. J. Klish, W. W. Wong, and P. D. Klein. 1988. Total body water estimated by measuring total-body electrical conductivity. Am. J. Clin. Nutr. 48:946.

Domermuth, W., T. L. Veum, M. A. Alexander, H. B. Hedrick, J. Clark, and D. Eklund. 1976. Prediction of lean body composition of live market weight swine by indirect methods. J. Anim. Sci. 43:966.

Fiorotto, M. L., W. L. Cochran, R. C. Funk, H.-P. Sheng, and W. J. Klish. 1987. Total body electrical conductivity measurements: effects of body composition and geometry. Am. J. Physiol. 252: R794.
Forrest, J. C., C. H. Kuei, M. W. Orcutt, A. P. Schinckel, J. R. Stouffer, and M. D. Judge. 1989. A review of potential new methods of on-line pork carcass evaluation. J. Anim. Sci. 67: 2164.

Funk, R. C. 1991. Electromagnetic scanning: Basis and recent advances in technology. Proc. Symp. on Electronic Evaluation of Meat in Support of Value-based Marketing, Purdue University, W. Lafayette, IN. p 73.

Gu, Y., A. P. Schinckel, T. G. Martin, J. C. Forrest, C. H. Kuei, and L. E. Watkins. 1992. Genotype and treatment biases in estimation of carcass lean of swine. J. Anim. Sci. 70:1708.

Gwartney, B. L., C. R. Calkins, R. J. Rasby, and J. C. Forrest. 1992. Predicting lean content of beef cuts using electromagnetic scanning. J. Anim. Sci. 70(Suppl. 1):56 (Abstr.).

Harrison, G. G. 1987. The measurement of total body electrical conductivity. Hum. Biol. 59:311.

Lin, R. S., J. C. Forrest, M. D. Judge, and R. P. Lemenager. 1992. Application of electromagnetic scanning for lean prediction in beef primal cuts. J. Anim. Sci. 70 (Suppl. 1):220 (Abstr.).

Mallows, C. L. 1973. Some comment on Cp. Technometrics. 15:661.

Milliken, G. A., and D. E. Johnson. 1989. Analysis of Messy Data Volume III. Analysis of Covariance. Chap. 2. Dept. of Statistics, Kansas State University, Manhattan.

Presta, E., J. Wang, G. G. Harrison, P. Bjorntorp, W. H. Harker, and T. B. Van Itallie. 1983. Measurement of total body electrical conductivity: A new method of estimation of body composition. Am. J. Clin. Nutr. 37:735.

SAS. 1990. SAS User's Guide: Statistics (Version 6.06 Ed.). SAS Inst. Inc., Cary, NC.

USDA. 1988. Institutional Meat Purchase Specifications. USDA, Washington, DC.

Van Loan, M., and P. Mayclin. 1987. A new TOBEC instrument and procedure for the assessment of body composition: Use of Fourier coefficients to predict lean body mass and total body water. Am. J. Clin. Nutr. 45:131. 